\title{
AISASモデルにみる口コミの形成過程における プランニング作法の提案
}

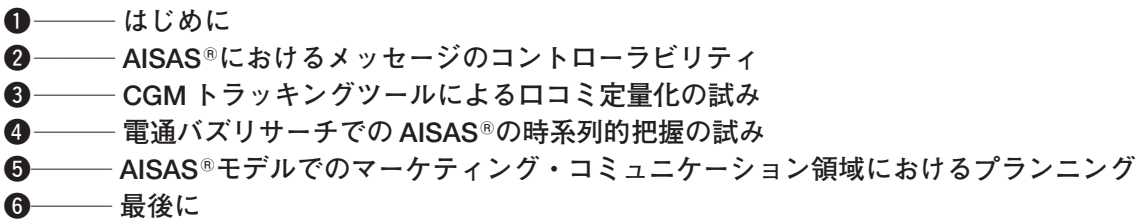

\section{森岡 慎司}

株式会社電通関西支社 インタラクティブ・コミュニケーション局

\section{長谷川想}

株式会社電通関西支社 インタラクティブ・コミュニケーション局

\section{山川 茂孝}

株式会社電通関西支社 マーケティング局

(1) はじめに

広告主協会が実施したアンケート［電通報， 2006]によれば，現在の広告担当者の主要課題 として，ネットを含むクロスメディアプランニ ングを挙げている企業が実に $63.2 \%$ も存在し ており，単媒体もしくはマス 4 媒体を中心とし た旧来のプランニングに代わる，新たな広告プ ランニングの作法が求められていることが実感 される。そもそも広告プランニングにおいては, プランナーは消費者が広告によりどのように態 度変容を起こすか，理解しておくことが必要で ある。AIDMA（Attention-Interest-DesireMemory-Action）モデルはシンプルで親しみ やすく，かつ市場が比較的単純であった時代に は有益なモデルとされてきた。しかしながら， 現在の市場は，その情報構造そのものが大きく
変貌しており，かつ認知から購入にいたるプロ セスも複雑化している。

杉山，秋山（2004）は，インターネットの 普及により，消費者がネット上で検索し商品 に関する情報を集め購入の意思決定を行い， またブログなどを通じて自分の意見をシェア する，という昨今の消費者の行動を捉え， AISAS ${ }^{\circledR}$ (Attention-Interest-Search-ActionShare）という消費者行動モデルを提案して いる。従来から映画などのような経験財の購 入プロセス ${ }^{11}$ や新商品の普及モデル ${ }^{2)}$ などの 耐久財の普及モデルでは，批評家によるレイ ティングやアーリーアダプターの意見が，消 費全体に大きく影響することは知られてきた。 昨今では，情報技術の普及による検索技術の 普及と，CGM（Consumer Generated Media） の台頭により，また，様々な財が経験財化す るにつれ，検索と口コミの伝播が消費に与え る影響が強くなってきている様子を，AISAS ${ }^{\circledR}$ は端的に表現していると言えるのではなかろ うか。

本論文では CGM の収集・分析の手法と事 例を通じて，企業がマーケティングに活用し ていく可能性として，特にマーケティング ・ コミュニケーション領域におけるプランニン 
グ作法を論じる。CGM が登場，普及した今日 では，消費者間で活発な情報流通が行われる ようになり，企業と消費者の関係が “BtoC” から”BtoCtoC “に変質しつつあると筆者は 考えている。これから述べるプランニング作 法とは, ”BtoCtoC “の中で新たに登場した” CtoC”の情報流通について，マーケティン グ・コミュニケーション領域の枠組みを用い つつ，実証的な観点から知見として蓄積しつ つあるものである。

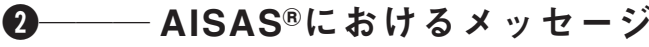 のコントローラビリティ}

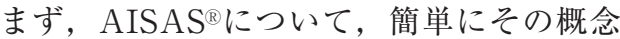
を説明する。AISAS ${ }^{\circledR} の$ A とIは，従来の AIDMA と同じ, 注目・興味である。マスマ ーケティングの観点からすると，A と I を獲 得するドライバーとしては，マス広告が挙げ られる。もちろん，様々な PR 活動も A と I を醉成するために用いることが多い。 AISAS ${ }^{\circledR}$ における最初のS（Search）である検索は， いわゆる検索エンジンなどのインターネット 上の検索を想像しがちだが，それ以外にも 「友人に評判を聞く」など，オフラインも含め 広い意味での情報検索活動として定義するべ きだと筆者は考える。実際，ネットに話を限 ってしまうと，消費者の行動の一部しか見て いないことになる。例えば，米国の調査会社 comScore（2004）によると，ネットで家電に ついて検索した消費者のうち，消費行動に結

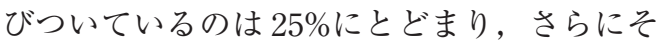
の $92 \%$ はオフインで購入していたと報告し ている。すなわち，検索や購入をネットに限
定するのはやはり現実的にはまだ無理があり, オンラインとオフライン，両方を含めて AISAS ${ }^{\circledR} し て$ 捉えるのが自然である。

ところで，検索のSに関しては，企業は広 告のようにはメッセージや情報に関して大き なコントロールが出来なくなる。確かに，ネ ットでの検索では，検索連動型広告を用いる ことにより，企業がコントロールするメッセ ージを表示することは可能であるが，広告で はない検索結果は $100 \%$ コンロールするこ とは出来ない3）消費者は広告と検索結果の どちらを選ぶか，最終的な権利を持つ。

消費者の検索行動では，検索エンジンのよ うなデータ化されたものばかりを探すわけで はない。友人に商品の評判を聞いたり，また 雑誌の記事や様々なランキング情報などから 情報を得ることもある。これらの情報源にも 企業のコントロールの度合いに違いが存在す る。仲の良い有人の情報は信用しやすいだろ うし，雑誌に書いてある情報は，ある程度企 業からの情報に染まっているものだというパ 一セプションがあるかもしれない。実際，企 業も PR 活動を通じて記事に自分たちの商品 のセールスポイントを取り上げてもらえるよ うに努力をするし，記者も社会的規範の中で 活動を行っており企業を陥れるようなことは よほどのことが無い限り行わない。例えば映 画の批評の場合，辛口と呼ばれる人でも誹謗 中傷にあたるような批評を書かないし，消費 者もそう思っているのではないだろうか。

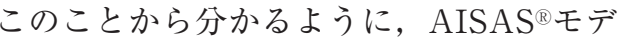
ルにおいては，検索行動の中の情報には，企 業がコントロールできるものと，そうでない ものが混在し，情報伝達が行われていること 
がわかる。しかも，同じ「評判」というくく りでは見えにくいが，雑誌記事など何かしら の媒体を介し，ある程度企業のコントロール を経た情報とそうでない情報があり，消費者 はこれらを見分ける能力を有している。企業 が消費者を偽って書き达みを行い，それが一 般の消費者に知れわたり，厳しい批判にさら された事例は枚挙に暇がない。コミュニケー ションプランニングに携わるものは，コント ロールできないものを無理やりしようとする のではなく，むしろどうやって付き合ってい くかに注力すべきであることは明らかである ${ }^{4)}$ さて, $\operatorname{AISAS}^{\circledR} の 2$ 番目の $\mathrm{A}$ は, アクショ ン。AIDMAの 2 番目の A と同じ購買行動で ある。そして最後のSである Share だが，こ の部分で中心的な役割を担うのが口コミであ る。ネットの出現により電子掲示板, ブログ, SNS（Social Network Service）などの口コミ の伝達媒体が増えたことは，消費者の情報発 信の場を増やしたばかりでなく，検索エンジ ンのロボットにそれらコンテンツが収集され， 検索の際の情報にフィードバックという情報 のループが出現したことに, むしろコミュニ ケーションの革新があったのでは無いかと思 う5)。このループにより何かに興味を持った

\section{表—— 1}

コミュニケーション手法とメッセージのコントローラビリティ

\begin{tabular}{|c|c|c|c|}
\hline 手法 & 情報の発信元 & AISAS $^{\circledR}$ の場面 & $\begin{array}{c}\text { メッセージの } \\
\text { コントローラビリティ }\end{array}$ \\
\hline 広告 & 企業 & A & 可能 \\
\hline PR & マスコミ & $\begin{array}{c}\text { 企業発の情報、批評·感想 } \\
(=\text { Share情報)をマススディィ } \\
\text { (=最初のA)で伝達 }\end{array}$ & ある程度可能 \\
\hline CGM & 消費者 & AISAS ${ }^{\circledR}$ の各場面 & 困難 \\
\hline
\end{tabular}

図-1

$\mathrm{AISAS}^{\circledR}$ のフィードバックループ

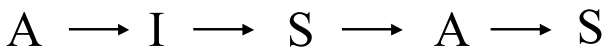
Attention Interest

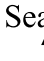

Action Share

消費者は，検索エンジンを通じて簡単に自分 と同じ興味関心のある人々の「情報シェア」 の輪に入れるようになった。

もちろん企業が口コミを重要視するのは， 検索のコンテンツが増えたからではない。ロ コミそのものが注目と興味（A と I ）のドラ イバーとして機能していると考えているから である。目立った広告活動もなしにモノが売 れる，といったサクセスストーリーは確かに 魅力的ではあるが，果たしてそのような口コ ミが企業の思うとおりに，いつもコントロー ルできるものかは疑問である ${ }^{6)}$ 。また，後ほ ど事例を示すが，口コミの範囲が自然に国民 的レベルまでに広がる例はそれほど多くなく， 販売目標が大きなナショナルプロダクトのマ ーケティングの際には，口コミの自然な伝播 を待っていてはとても間に合わない。

\section{3) CGMトラッキングッールに よるロコミ定量化の試み}

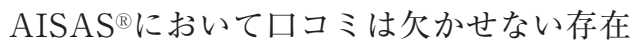
であったが，そのコントロールは従来手法の 広告や PRに比べ困難である。コントローラ ビリティを確立するために，まず大切なこと は，口コミの内容並びに量を計測するすべを 確保することである。その手法の一つとして， 
この節ではネット上の口コミの計測システム 「電通バズリサーチ powered by GALA」（以 下電通バズリサーチ）を紹介する。

ところで，先に Share の中心であるロコミ は，友人・知人，家族などとの情報交換も含 め定義すべきであると述べたが，インターネ ットから得られた情報を利用し，市場全体の 動向を把握しょうという考え方は，市場調查 をはじめ，口コミの計測でもしばしば用いら れる考え方である。例えば，David and Mayzlin（2004）は, USENETのディスカッ ションを分析し，オフラインの媒体であるテ レビ番組の視聴率との関係を研究しており, ネットのロコミの計測の有効性を主張してい る。ただ，清水（2004）が指摘するように， ネットの声はただ集めればよいものではなく， 製品特性などにあわせ活用方法を変えていく 必要があることは，マーケティングプランニ ングの上で留意しておくべきである。

さて，電通バズリサーチは消費者同士が 日々ネット上でコミュニケーションしている
電子掲示板やブログに書かれている書き込み を定量的・定性的に把握するための調査シス テムである。調査したいブランド名や企業名 を設定し，新開発した検索ロボットが主要な CGM サイトを巡回，設定したワードを含む新 たな書き込みの内容をリアルタイムで把握・ 分析するシステムでASP 方式で提供している。

定量的には日々新たに書き込まれた書き込 みの件数をデイリーに集計し，書き込まれた 内容をシステムが持つ辞書機能でポジティブ あるいはネガティブなワードを含んでいるか を自動的に判定して件数を表示し，回収した 書き达みがポジティブ・ネガティブのどちら の傾向にあるのかを把握できる。また，定性 的には回収した書き込みの抜粋文を確認する ことが可能で，実際消費者がブランドや企業 をどのように表現しているかも把握すること ができる。

電通バズリサーチには回収した書き込みを 分析する機能として，「ワードランキング」, 「キーワードソーター分析」，「キーワードクラ

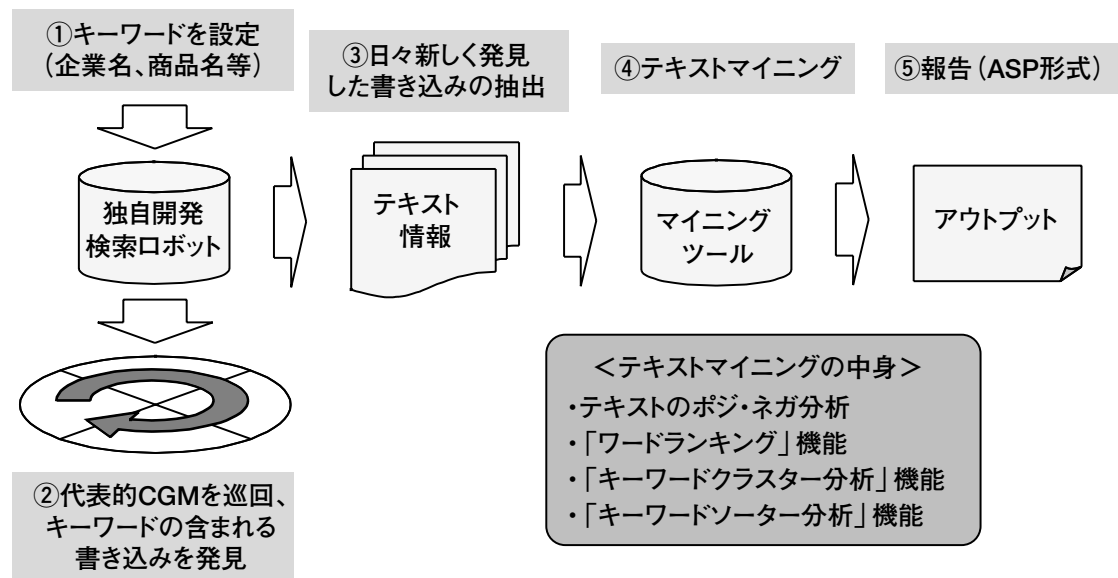


スター分析」の機能を搭載している。「ワード ランキング」機能は回収した書き込みを形態 素解析によって単語に分割して品詞別の集計 を行い，出現頻度の高いものから表示する。 ブランド名や企業名などと一緒に語られてい る単語を知ることで，消費者がどんなイメー ジを持っているか指標づくりに役立つ機能で ある。「キーワードクラスター分析」は回収し た書き込みを自動的に分類し，どのような話 題軸がどれくらいのボリュームに分かれてい るのかを表示，話題軸どうしの関係性もある 程度把握することができる機能である。「キー ワードソーター分析」は回収した書き达みを 例えば，「機能」，「デザイン」，「価格」など， 予め設定したキーワードでソート，各々のボ リュームを件数で把握可能で，実際書き込ま れた書き込みの抜粋文も確認することができ る。なお，電通バズリサーチでは，2 ちゃん ねる，livedoor Blogなどの代表的な CGM の 12 サイト（2006 年 5 月現在）を巡回の対象に している。

電通バズリサーチを利用することによって， コントロールが困難なネット上のロコミを大 枠で把握することが可能である。これまでの 調査事例からは記者発表，広告などの企業の マーケティングアクションやマスメディアヘ の露出とネット上の口コミである CGM 上の 動きには高い相関関係が見られた。つまり， コントロールが容易な広告とコントロールが 困難な CGM は各々が単独で存在している訳 ではなく，お互いが何らかの関係性をもちあ う存在であることが推測される。ただ，両者 の間に一定の法則のようなものが存在してい るのかは今後事例を蓄積しながら慎重に検討
していく必要があると思われる。次章では具 体的な電通バズリサーチの調査結果の事例か ら両者の関係性について考察したい。

\section{4—電通バズリサーチでの AISAS ${ }^{\circledR}$ の時系列的把握の試み}

電通バズリサーチのように，一部であると はいえ，口コミの流通量をシステマティック に把握することは, ロコミの挙動の把握にお いて大変重要である。ここで，いくつか事例 を示し，ロコミプランニングに関し有益と思 われる示唆を導きたいと考える。

まず，第一の事例として，「恋のマイアヒ」 の事例を示す7)。「恋のマイアヒ」は，モルド バ出身の 3 人からなるルーマニアの音楽グル ープ O-ZONEの楽曲「Dragostea Din Tei」 のことである。この楽曲は 2003 年夏ごろルー マニアで爆発的ヒットを飛ばし，2004 年にヨ ーロッパに飛び火。夏ごろには，ドイッ，フ ランス，ベルギー，スペイン，イタリアなど ヨーロッパ15 カ国でNo.1 ヒットとなった。 累計 400 万枚超のセールスとのことである。 言語が異なるため，歌詞の意味がわからない ものの軽妙なリズムと「マイアヒーつ」とい う歌詞は確かに記憶に残る。名古屋の ZIPFM では 2004 年 10 月にチャート 1 位となって おり，洋楽に詳しい人々の間では知られた存 在となっていた。

ネットの世界では 2 チャンネルを中心に 「空耳フラッシュ」が話題を呼ぶようになり， ロコミで広がっていった ${ }^{8)}$ 口恋のマイアヒ」 の販売を手がけるエイベックスはこのフラッ シュに出てくる猫のキャラクターに注目。CD 
発売の 2005 年 3 月, 渋谷を猫のキャラクター (エイベックスは「のま猫」と呼んだ9) ${ }^{9}$ )で埋 め尽くす宣伝を行った。この渋谷での展開は ネットユーザーの目にも留まり，掲示板など でも話題となった。しかしながら，ネットで の口コミを決定付けたのは，O-Zone が同年 7 月にミュージックステーションに出演してか らである。(以下のグラフ参照）さらに $\mathrm{SMAP} \times \mathrm{SMAP}$ で取り上げられるなど，テレ ビで話題になると書き込みが急増するという 現象が続くこととなる。ところで，「恋のマイ アヒ」が収録されているアルバムがオリコン 1 位になったのは 8 月 22 日。発売から 24 週目。 この「恋のマイアヒ」の事例は，まさに消 費者が作り出したキャラクターから火が付き, それがビジネスへと展開されたものである点 で，極めて興味深い。しかしながら，ビジネ スへの波及，すなわち CDの売り上げの観点 からは，テレビへの露出が契機になっている ことも無視は出来ない。また書き込みもそれ に比して増加している。AISAS ${ }^{\circledR} に$ 照らした 場合，この事例は一部のイノベーター的消費 者がShareを開始し，テレビによって興味を

\section{图-3}

\section{『恋のマイアヒ』のロコミ増加推移（日別）}

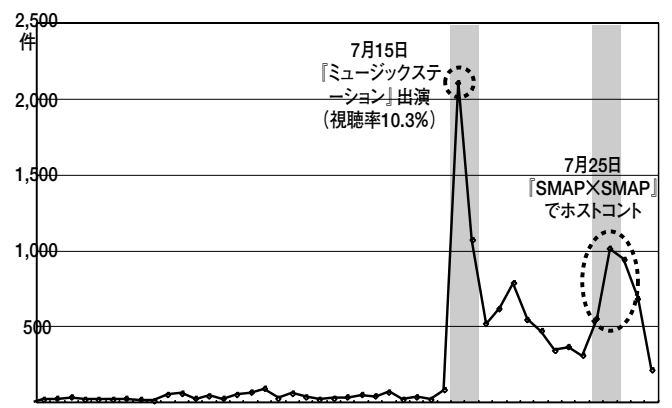

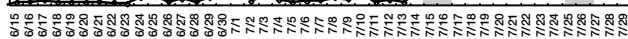

「電通バズリサーチ」調查結果より
抱いた一般消費者がSASのループに流入して きたと見ることが出来る。

上記事例は口コミ，Share が先行していた が，実際のマーケティングでは逆で，ロコミ の種を上手に市場に蒔いていく作業が必要と なる。新発売キャンペーンでは, なおさらで ある。以下，詳細は明かすことは出来ないが， ロコミを含む「話題性」を意識した事例を 3 つ紹介する。

事例 1 高関与玩具

概要: 有名タレントのティザー広告展開後, 大規模な体験イベント実施，その後発 売開始

新商品発売のニュースリリース後，スペッ クや価格に関する書き达みが見られ，その後 有名タレントのティザー広告が開始されると その $\mathrm{CM}$ のタレント，衣装，音楽に関する書 き込みも見られた。発売直前になって体験イ ベントが実施されると，そのイベントへの参 加者によると思われる書き达みが大幅に増加 した。発売開始後は品薄の報道もなされ，ま た発売開始後の約 10 日後には競合社が大型の 競合商品を発売開始し，さらに大幅な書き达 み量となった。またこの玩具に関する書き込 みは，競合商品のものも含めて 2 ちゃんねる 上で大部分のものがなされた。

事例 2 アルコール飲料

概要：競合が激しいカテゴリーでの後発ブラン ド，テレビやWeb 広告を集中的に展開 本事例については，CGM 上の書き込みだけ 
でなく，代表的なポータルサイトの検索回数 も計測を行った。テレビスポット広告は発売 開始後の 2 週間以内に大量に投下されたが, テレビスポット出稿と検索回数のいわゆる 「やま」は同時期で，テレビスポット広告開始 後 8 日目に一日の最大の検索回数を記録した。 一方書き込み件数はテレビスポット広告開始 後 12 日目に一日の最大の書き込み件数を記録 するにいたった。日別の検索回数と書き込み 件数には一定の相関関係が確認できた。また, テレビスポット広告終了後のいわゆる残存効 果であるが，検索回数はテレビスポット広告 終了とともに大きく減少したが，書き达み件 数は検索回数と比べ減少幅が小さくとどまっ た。また本商品に関する書き込みはブログを 中心に行われ，飲んだ感想などを書き込んで いる例が多く見うけられた。

事例 3 新カテゴリー家電商品

概要：環境訴求の新しいカテゴリーの低額家 電商品で, 発売当初にテレビ広告を中 心に限定的に広告展開

新カテゴリーの商品で，そのベネフィット が分かりやすく，テレビスポット広告開始と ともに順調に書き込み件数を増加させた。本 事例の特徴は，テレビスポット広告の展開は 限定的であったが，広告終了後も書き达み件 数は減少することなく，むしろ増加の傾向を 有していたことである。新カテゴリーの商品 であるためか，実際に使用した体験に関する コメントを中心にそのスペックの評価などに 関する書き込みが継続した。またこの家電製 品に関する書き达みは，2ちゃんねる上で大
図- 4

事例 3 日別のテレビスポット出稿量と書き込み件数 一東京地区テレビ出稿量 一 新商品X書き込み件数

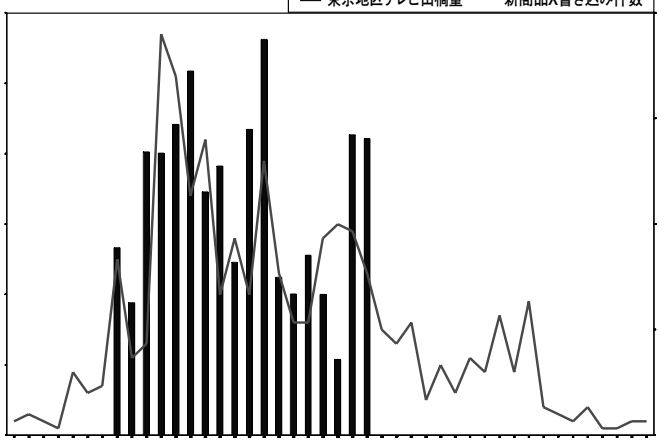

部分のものがなされた。

1 ケ月あたりの書き込み件数は，事例 1 で は約 12,000 件（事例 $2 ：$ 約 100 件, 事例 3 ： 600 件）となっていたが，書き込みのボリ工 一ムはその商品特性に依存するものと思われ る。当該商品に関心を媣く有するユーザが固 定的に存在し，それらのユーザによって多く の書き込みはなされたものと思われる。2 ち やんねる上には，当該商品に関するスレッド が多く立ち上がり，関心を共有するユーザ同 士間でそのスペックなどに関する書き込みが 多く増加していったものと思われる。書き込 む行動そのものは，自らの関心領域を共有す る他のユーザが存在することを前提になされ ているとも言えよう。また体験イベントや発 売開始によって急激に多くの書き込みがなさ れた理由としては，それまではメディアを通 じた情報が均質に消費者に伝えられていたが， イベント参加や購入によって, 当該商品を体 験して得た自分なりの評価を 2 ちゃんねるな どの「場」に行ったと言える。またその評価 
の書き込みにあたっては, 話題の新商品でも あり，均質な情報を超えた，「人より早く体験 し，自分だけが知っている」という体験を通 じた情報格差が書き込みを誘発していると言 えよう。

事例 2 では, 事例 1 ほど書き込み件数は多 くはないが，飲んだ際の当該商品に対する評 価などがブログを中心に書き込まれた。書き 込む動機はユーザ間のコミュニケーションと は想像し難く，テレビスポット広告が大量に 投下され話題になりそうな商品を「流行を先 取りし，いち早く試した」というこれも体験 を通じた情報格差が書き込みを誘発している と言えよう。また本事例については，前述し たとおり，書き达み件数のピークは，検索回 数のピークやテレビスポットの出稿のピーク からやや遅れて現出した。これは，先に述べ た $\operatorname{AISAS}^{\circledR}$ モデルを時系列で実証していると いえる。また残存効果が高かったことからも， 検索の S と比べて共有の S は, 長い時間をか けて行われるということも実証されたが，情 報シェアの「輪」のタイミングの「ずれ」を 考慮することで，ますます有効なマーケティ ングプランニングが実現できる可能性がある と筆者は認識している。

事例 3 では，新カテゴリーの商品であると 述べたが，同商品はいわゆるコモディティ商 品であり, 月間 600 件程度の書き込みは我々 の予想を超えるものであった。新カテゴリー のため，その商品に関する有関心層はそれま で存在していなかったと言えるが，前述した ようにテレビスポット広告終了後もそのスペ ックに関する書き达みが 2 ちゃんねる上を中 心に継続した。これは環境や節約などのべネ
フィットが有用であるとの評価がなされ， CGM 上でコミュニティが登場し, そのコミュ ニティ上で自らの使用体験などを共有しつつ, 「この商品は本当に使えるのか」というょうな 当該商品のスペックを評価する書き込みが多 くなされたといえる。コモディティ商品であ っても，「評価を消費者にさせる」という形で ロコミ上では高関与型の捉えられ方をする場 合もあり，今日増えつつある機能性のコモデ イティ商品などのマーケティングプランニン グにあたっては，検討に值する事例と言えよ う。

\section{5) AISAS ${ }^{\circledR} モ$ デルでのマーケテ ィング・コミュニケーション 領域におけるプランニング}

ロコミの広がりは，コントロールが非常に 難しく，企業の無理な介入はかえって危険で あることは言うまでもない。しかしながら， 企業が消費者とコミュニケーションを円滑に 図るためには，何かしら口コミをナビゲーシ ヨンする方策を考えなければならない。

先の章で議論したように，一般的には口コ ミは情報を所有する者とそうでない者の間に 明らかな「情報格差」が存在するときに発生 する場合が多い。また，情報を所有するもの が口コミを発生させる場合には，聞き手がそ の情報を受容する素地があることを暗に仮定 していることが多い。例えば，電子揭示板で あれば，スレッドという共通の「場」の中で ディスカッションが進むのであって，まった くの通りすがりの人に話し掛けているわけで はない。ブログや SNS に関しても，ある種の 
統一テーマやそれぞれのメンバーの関係の上 で成り立っている ${ }^{10)}$ 。先の事例であれば，「イ ベント告知」により多くの消費者はイベント の存在を知っている，という意味で共通の情 報素地が出来ていたと見ることができる。

では，企業のマーケティング活動の中で口 コミをコントロールしながら最大限活用する ためにはどうすべきであろうか。今までの考 察から考えられることをまとめると，ひとつ は情報格差を作ること，もうひとつはその情 報格差を流すべき素地をマーケットに作り出 すこと，の 2 点である。

情報格差は, 新カテゴリーの商品, 耐久 財・サービスなど経験・体験が重要な財の場 合には，「購入経験者・体験者」とそうで無い 者の中に自ずと生じる。しかしながら，一般 消費財の場合は，マーケティング施策の中で 作り出す必要がある。イベントなどで発売に 先行して「体験者」を作るとか，もしくは 「恋のマイアヒ」のように，イノベーターやア ーリーアダプターしか知らない「ネタ」の存 在をマスメディアを使って広め，今まで情報 格差を意識していなかった一般の消費者へ 「格差」を認識させることも一つの手段である。

次に「場」の設定だが，ブログや掲示板の 設定など，物理的なデイスカッションの場を 作るのも確かに必要であるが，一般に企業が ターゲットとしているマーケットは掲示板レ ベルのコミュニティよりはるかに広く，狭い 「場」だけではビジネスは成り立たない。ある 時点で一気に市場を広げる策が必要となるが, 先の事例を見て分かるように，その起爆剤と してマスメディアは大変有効である。繰り返 しになるが，ロコミを拡大するときのマスメ
ディアは，情報が流れるための素地（「情報格 差」）を作ることが目的であり，情報（ネ夕） そのものを全て示すことが目的ではない。情 報を与える方ももらう方も，お互いに楽しみ ながら情報伝達，ロコミできるような場の設 定が重要である。先に述べたが，口コミを無 理やり発生させる, 特に AI の時点に口コミ を企業が主体となって利用するのは難しいし， リスクも高い。しかしながら，マスメディア という強力な情報媒体を用いることによって， 場を積極的に提供することは不可能ではない。

最後に，プランニングの際に重要な要素と して，タイミングについて述べる。 AISAS ${ }^{\circledR}$ のプロセスは，事例 2 にあるように，ある程 度の夕イムラグを持ちながら進行する。ゆえ に，いつ何について情報格差を作り場を設定 するかについて, 時間軸を計算に入れプラン ニングを行う必要がある。ティザー広告，イ ベント, 商品広告などのパイプラインがバラ ンスよく配置されていることが，重要である。 またShareのフェーズでは，当初想定した内 容以外の話題も発生する可能性も高く, 口コ ミをモニタリングすることは大変重要であり, また時々刻々変化する口コミに応じてコミュ ニケーションの内容も変化させていく必要が ある。プランニングも一回作って終わりでな く，柔軟に変化させていくことが望まれる。

\section{6一最後に}

1990 年代は企業が情報技術を活用し，CRM (Customer Relationship Management) など, 企業と消費者の双方向な関係に焦点があたり， 顧客志向が特に強調された。消費者の情報を 
出来る限り入手し，その顧客あった対応を行 うべきものとされた。ここでの BtoCの関係 はインタラクティブではあるが，単線的にと らえられている。一方 CGM が登場，普及し た今日では，顧客同士で活発な情報流通が行 われるようになり，一人の顧客を無数の消費 者とコミュニケーションチャネルを持った顧 客として対応する必要が出てきた。消費者の ことを知るだけでなく，その消費者が接する， あるいは発する口コミまでをも考慮した対応 を行う必要がある。これまでのマス広告を中 心に位置付けた企業発のメッセージがいかに 広く，深く消費者に届くかを追求したモデル とは異なる素地が出来上がりつつあると言え る。AIDMAが “BtoC”を想定したモデルで

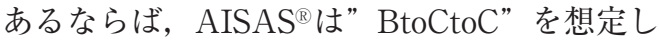
たモデルと言えよう。“CtoC”の情報流通は， 前述したとおりコントロールできるものでは ないが，今日消費者の購買行動に大きな影響 を及ぼすなど企業のマーケティング・コミュ ニケーション展開にとって無視できない存在 になりつつあることもまた自明である。筆者 は” CtoC” の情報流通を把握するッールの開 発を通じ，様々なマーケティングアクション とその結果としての情報流通状況の関係性の 分析を試み，この結果「情報格差」と「場」 というヒントを得ている。今後, マーケティ ング戦略上有用な”CtoC”の情報流通の類型 化，プランニングのフレーム作りなどには多 く事例を収集，分析する必要があるなど課題 は多くあるが，より精緻かつ実践的な作法の 提言のために検証活動を重ねていきたいと考 えている。
注

1）山岡（2005）は，調査の結果，ネットロコミを選 択購入の参考にした商品・サービスカテゴリーと して，「ホテル，旅館，リゾートなど」「パソコ ン・周辺機器」「映画やコンサート」などの回答率 が高かったと報告している。これらはいずれも体 験者の感想以外は参考になりにくいソフトやサー ビス，技術関連知識に関わる，経験財である。

2) Bass （1969）以降，普及モデルにロコミ効果を取 り入れたモデルとしては, Dodson and Muller (1978）やMahajan (1984）がある。

3）検索エンジン最適化（SEO）により，検索結果を 改善することは可能であることは, 付記しておく。

4) WOMMA (Word-of-mouth Marketing Association) も，口コミマーケティングで大切なことは，消費者 とそのコミュニティーに謙虚にかつ正直な姿勢で接 するべきであり，ステルスマーケティングのように 消費者を欺くような行為は行うべきではないとして いる。

http://www.womma.org/wom101c.htm

5）Dellarocas（2004）は，eBayなどにおける評判シ ステムのようなフィードバックシステムが，ネッ 卜上の市場での取引の際の重要な情報源となって いると指摘している。口コミがIT 化によりデータ 化され，蓄積されることのインパクトは大きい。

6）口コミが直接 AI を醸成する例としては，友人との 会話の中に商品の話題が出て来て, それが購買へ とつながる，といった状態である。このプロセス に企業が介入する場合，ステルスマーケティング のような「だまし討ち」的な手法を取らざるを得 ないことが多いのではなからうか。なお，口コミ マーケティングに関する書籍の多くは，インフル エンサーやロコミネットワークのハブと呼ばれる 人たちにアプローチするという手法を議論してい るものが多い。筆者はこれらの手法は PR 手法に近 いと考えている。なお，それら口コミマーケティ ングに関する書籍に関しては，WOMMAのウェブ サイトに多くリストアップされており，そちらを 参照されたい。

7）「恋のマイアヒ」に関する情報は，Wikipedia（日 本版）に詳しい。本論文の記述も，その多くを Wikipediaにおっていることを付記しておく。

8）米国では19歳の少年が踊る「numanuma dance」 フラッシュが話題となり，テレビ番組で取り上げ られ全米に知れ渡る結果となった。

9）「のま猫」は，2 チャンネルを中心に流通してい る文字絵の「モナー」を真似たものだとして，エ イベックスはその後ネットユーザーから厳しい非 
難を受けることになるが，本論文の趣旨とは異な るため，割愛する。また，SMAP $\times$ SMAPでの楽 曲の利用は 4 月 19 日から。その際，オリコンは 265 位から 133 位に浮上。

10) 南博（1976）は, Dichter,E.（1966）の調査結果を 引用し，口コミの話し手として，利害関係のない 友人 $(38.5 \%)$ の次に, 消費者意識を共有する者 $(28.0 \%)$ としている。より詳細な議論を行うため には，口コミの伝い手，受け手，その二人の社会 的，心理的，情報流通的関係性などについて議論 する必要がある。口コミに関するより構造的な議 論ならびに関連文献についてはOzcan （2004）に 詳しい。また本論は実務上の明快さを重視し,「情 報格差」と「場」というシンプルな表現を用いている。

\section{参考文献}

秋山 隆平, 杉山 恒太郎（2004）『ホリスティック・コ ミュニケーション』宣伝会議

清水信年（2004）“インターネットで収集する消費者 情報と製品開発” マーケティング・ジャーナル， No. 94 , pp.18-30

電通報（2006）「日本広告主協会が調査リポート 『2006 年重点広告戦略の方向』発表」第 4510 号 (http://www.dentsu.co.jp/books/dhou/2006/h45 10-060116/index2.html)

山岡 拓（2005）“口コミ情報と新聞広告の役割〜企 業情報の提供の在り方を考える”，日経広告手帖， 9 月号, pp. 18-24

南博・社会心理研究所（1976）『くちコミュニケーシ ヨン』(誠信書房) ,P191-193

Bass, Frank (1969) , “A New Product Growth Model for Consumer Durables” , Management Science, 15 (January) , 215-227

comScore (2004), "comScore Study Reveals the Impact of Search Engine Usage on Consumer Buying” http://www. comscore. com/press/release. asp? pre ss $=526$

Dellarocas, Chrysanthos, Neveen Farag Awad and Xiaoquan (Michael) Zhang (2004) “Exploring the Value of Online Reviews to Organizations: Implication for Revenue Forecasting and Planning" Working paper, MIT

Dellarocas, Chrysanthos (2003) “The Digitization of Word of Mouth: Promise and Challenges of Online Feedack Mechanisms, " Management Science, Vol. 49, No. . 10, pp. 1407-1424

Dodson Jr., Joe A. and Eitan Muller (1978) “Models of New Product Diffusion through Advertising and Word-of-Mouth”, Management Science, Vol. 24, No. 15, pp. 1568-1578

Godes, David and Dina Mayzlin (2004) “Using Online Conversations to Study Word-of-Mouth Communication" , Marketing Science, Volume: 23, Number: 4. Pgs: 0545-0560

Mahajan, Vijay (1984) “Introduction Strategy for New Products with Positive and Negative Wordof-Mouth” , Management Science, Vol.30, No. 12, pp. 1389-1404

Ozcan, Kerimcan (2004), "Consumer-to-Consumer Interactions in a Networked Society: Word-ofMouth Theory, Consumer Experiences, and Network Dynamics," Unpublished Ph.D. Dissertation, University of Michigan.

\section{森岡慎司（もりおかしんじ）}

1984 年関西学院大学社会学部卒業後, 同年株式会社 電通入社。

マーケティング局を経て現職。

バズマーケティング領域に取り組んでいる。

現職，インタラクティブマーケティング部部長。

\section{長谷川 想（はせがわそう）}

1994 年一橋大学法学部卒業。

同年日本電信電話株式会社入社。

2000 年株式会社電通入社。

2004 年東京大学大学院学際情報学府修士課程修了。

現職, インタラクティブマーケティング部主務。

山川茂孝（やまかわしげたか）

1991 年慶応大学理工学部卒業。

1993 年同大学院理工学研究科修士課程修了。

米国ロチェスター大学サイモン・ビジネススクール 博士課程に留学後, 国際大学大学院国際経営学研究 課助手, 同ソフトウェアセンター主任研究員を経て, 1999 年株式会社電通入社。

Ph. D. (Business Administration)

現職,メディアリサーチ部部長。 